KEMAS 11 (2) (2016) 163-172
Jurnal Kesehatan Masyarakat

\title{
ESTIMASI DAMPAK EKONOMI DARI PENCEMARAN UDARA TERHADAP KESEHATAN DI INDONESIA
}

\author{
Djoko Mursinto ${ }^{1}$, Deni Kusumawardani ${ }^{2 \bowtie}$ \\ 1,2 Departemen Ilmu Ekonomi, Fakultas Ekonomi dan Bisnis, Universitas Airlangga
}

\section{Info Artikel \\ Sejarah Artikel: \\ Diterima 15 Juni 2015 \\ Disetujui 9 November 2015 \\ Dipublikasikan Januari 2016 \\ Keywords: \\ Mortality; Morbidity; \\ Dose-response; Value of \\ statistical life; Cost of illness \\ DOI \\ http://dx.doi.org/10.15294/ \\ kemas.v11i2.3677}

\begin{abstract}
Abstrak
Gangguan kesehatan merupakan salah satu dampak dari pencemaran udara yang paling dirasakan di negara-negara berkembang. Penelitian ini bertujuan untuk mengestimasi dampak ekonomi dari pencemaran udara terhadap kesehatan di Indonesia menggunakan data tahun 2011. Indikator pencemaran udara yang digunakan adalah benda partikulat atau particulate matter 10 (PM10). Dampak ekonomi diukur oleh besarnya biaya yang dikeluarkan akibat terjadinya gangguan kesehatan manusia, yang terdiri dari mortalitas dan morbiditas. Teknik estimasi melibatkan dua pendekatan, yaitu epidemiologi untuk menilai hubungan sebab akibat antara tingkat konsentrasi PM10 dengan risiko kesehatan, dan valuasi ekonomi untuk memberikan nilai dalam satuan moneter terhadap risiko kesehatan tersebut. Hasil estimasi menunjukkan besarnya biaya ekonomi yang ditimbulkan oleh konsentrasi PM10 terhadap kesehatan senilai Rp 373,1 triliun atau setara dengan 5,03\% Produk Domestik Bruto (PDB).Dari biaya tersebut, 60,9\% adalah biaya mortalitas berupa kematian dini dan 39,1\% adalah biaya morbiditas dengan komponen terbesar (sekitar 50\%) berupa perawatan rumah sakit akibat penyakit pernapasan. Masyarakat harus menanggung biaya pencemaran rata-rata sekitar Rp 1,53 juta atau $6,7 \%$ dari pendapatan per kapita.
\end{abstract}

\section{ESTIMATING THE ECONOMIC IMPACT OF AIR POLLUTION ON HEALTH IN INDONESIA}

\begin{abstract}
Health problemisone of the effectsofair pollutionthatmostly feltindeveloping countries. This study aims to estimate the economic impact of air pollution on health in Indonesia. Air pollution indicator used is particulate matter matter 10 (PM10). The economic impact is measured by costs incurred due to the occurrence of human health problems, which consists of mortality and morbidity. Estimation technique involves two approaches, namely epidemiology to assess the causal relationship between the level of concentration of PM10 with health risks, and economic valuation to provide monetary value on these health risks. The result indicates the economic costs caused by the concentration of PM10 to the health are Rp 373.1 billion, equivalent to 5.03\% of Gross Domestic Product (GDP). Of these costs, $60.9 \%$ is the cost of mortality in the form of premature death and $9.1 \%$ is morbidity which the largest component costs (approximately 50\%) of hospital admission for respiratory causes. Society must bear the cost of pollution on average about $R p 1.53$ million or $6.7 \%$ of per capita income
\end{abstract}

(c) 2016 Universitas Negeri Semarang

\footnotetext{
Alamat korespondensi:

Departemen Ilmu Ekonomi, Fakultas Ekonomi dan Bisnis, Universitas Airlangga

Email : deniku13@gmail.com
}

ISSN 1858-1196 


\section{Pendahuluan}

Pencemaran udara telah menjadi salah satu masalah lingkungan global yang menjadi perhatian dunia (Mulyadi, 2015). Survei yang dilakukan oleh World Health Organization WHO (2002) di 1.600 kota yang tersebar di 91 negara di dunia menunjukkan bahwa hampir $90 \%$ orang-orang di pusat perkotaan menghirup udara yang tidak sehat. WHO juga menyatakan bahwa sekitar setengah dari penduduk dunia terkena pencemaran setidaknya dua setengah kali lebih tinggi dari baku mutu kualitas udara yang ditetapkan. Fenomena tersebut terutama dirasakan di negara-negara berkembang seperti Indonesia sebagai dampaknegatif dari pembangunan yang berorientasi pada pertumbuhan ekonomi (Basri, 2014).

Dari berbagai jenis zat pencemar udara, benda partikulat atau particulate matter berdiameter 10 mikron $\left(\mathrm{PM}_{10}\right)$ mendapatkan perhatian khusus karena dinilai memiliki pengaruh lebih besar terhadap gangguan kesehatan manusia dibandingkan dengan zatzat pencemar lainnya. $\mathrm{PM}_{10}$ dapat dijadikan sebagai wakil dari zat-zat pencemar lain. Naik turunnya $\mathrm{PM}_{10}$ berasosiasi dengan zatzat pencemar lain yang berada di udara. Oleh karena itu, sebagai prediktor kesehatan $\mathrm{PM}_{10}$ mempunyai cakupan yang lebih luas. Pendapat senada dikemukakan oleh WHO (2011), yang menyatakan bahwa $\mathrm{PM}_{10}$ merupakan prediktor kesehatan yang baik.

Menurut WHO (2011) efek kesehatan dari paparan $\mathrm{PM}_{10}$ dalam waktu singkat dapat mempengaruhi reaksi radang paruparu, ISPA (infeksi saluran pernapasan atas), gangguan pada sistem kardiovaskuler, meningkatnya perawatan gawat darurat, peningkatan penggunaan obat, bahkan kematian. Sementara dampak jangka panjang $\mathrm{PM}_{10}$ dapat meningkatkan gejala gangguan saluran pernapasan bawah, eksaserbasi asma, penurunan fungsi paru pada anak-anak, peningkatan obstruktif paru-paru kronis, penurunan fungsi paru-paru pada orang dewasa, penurunan rata-rata tingkat harapan hidup terutama kematian yang diakibatkan oleh penyakit cardiopulmonary dan probabilitas kejadian kanker paru-paru (Nurjanah, 2014). Secara umum dampak kesehatan dari konsentrasi $\mathrm{PM}_{10}$ adalah gangguan pada sistem kardiovaskular, gangguan pernapasan, serta kematian. WHO (2014), melaporkan bahwa di seluruh dunia diperkirakan $\mathrm{PM}_{10}$ menyebabkan sekitar 16\% kematian akibat kanker paru-paru, $11 \%$ kematian akibat penyakit paru obstruktif kronis, dan lebih dari 20\% akibat penyakit jantung iskemik dan stroke (Sugiarti, 2009).

Di Indonesia rata-rata konsentrasi ambien $\mathrm{PM}_{10}$ selama periode 1990-2011 sekitar $56 \mu \mathrm{g} / \mathrm{Nm}^{3}$ dan pada tahun 2011 sendiri sebesar $46,74 \mu \mathrm{g} / \mathrm{Nm}^{3}$. Meskipun mengalami tren penurunan, namun angka tersebut melebihi ambang batas yang ditetapkan oleh WHO, yaitu sebesar $20 \mu \mathrm{g} / \mathrm{Nm}^{3}$ dengan waktu pengukuran selama satu tahun (KLH, 2012). Sumber utama $\mathrm{PM}_{10}$ di Indonesia berasal dari sektor transportasi (71\%) dan sektor industri 25\%, sedangkan sisanya (4\%) adalah sektor rumah tangga atau domestik.

Laporan WHO dan Kementerian Kesehatan yang menyebutkan bahwa penyebab kematian di Indonesia pada tahun 2011 didominasi oleh penyakit Non-Communicable Disease (NCD) atau Penyakit Tidak Menular (PTM) dengan proporsi $71 \%$ dari 1.551 .000 kasus kematian total. Berdasarkan jenisnya, penyakit kardiovaskuler seperti penyakit jantung, stroke, dan infark menjadi penyebab utama dari kematian (37\%), kemudian diikuti oleh kanker (13\%), penyakit pernapasan (7\%), diabetes (6\%), dan $10 \%$ penyakit PTM lainnya. Fakta tersebut mengindikasikan adanya korelasi yang erat antara tingginya konsentrasi $\mathrm{PM}_{10}$ dengan gangguan kesehatan, terutama PTM.

Dampak dari pencemaran udara terhadap kesehatan pada akhirnya akan menimbulkan beban ekonomi (economic burden) yang harus ditanggung oleh masyarakat. Beban ekonomi dari suatu penyakit meliputi tiga komponen biaya, yaitu: biaya langsung (direct cost), biaya tidak langsung (indirect cost), dan biaya yang bersifat tidak nyata(intangible cost). Biaya langsung berupa penggunaan sumberdaya untuk merawat dan mengobati sakit, yang dibedakan ke dalam dua jenis, yaitu biaya kesehatan (medical cost), seperti biaya berobat dan jasa konsultasi medis serta biaya non-kesehatan (non-medical cost) seperti transportasi menuju dan akomodasi selama di tempat berobat. Biaya tidak langsung 
merupakan nilai sumber daya yang hilang, yang meliputi biaya morbiditas dan mortalitas, biaya pengobatan informal, dan biaya kehilangan akibat tindakan kriminal. Sementara itu, intangible cost merupakan jenis biaya yang sulit diukur karena terkait dengan perasaan, baik fisik dan psikologi, seperti sakit, menderita, dan tidak nyaman (Sangkey, 2011).

Penilaian dampak ekonomi dari pencemaran udara terhadap kesehatan seringkali dihindari karena dua kesulitan yang sekaligus menjadi masalah utama, yaitu: (1) menetapkan hubungan sebab-akibat secara langsung antara pencemaran dan gangguan kesehatan; (2) mengestimasi nilai moneter pada dampak kesehatan akibat pencemaran. Masalah pertama merupakan bagian dari studi tentang penilaian risiko epidemiologi (epidemiological risk assessment), terutama terkait dengan penentuan ada tidaknya hubungan sebabakibat (cause-effect relationship) (WHO, 2002). Studi ini melibatkan beberapa tahap penilaian, yaitu identifikasi risiko kesehatan, penilaian eksposur (paparan pencemar), penilaian doseresponse, dan yang terakhir adalah identifikasi karakter dari masing-masing risiko kesehatan.

Masalah kedua, yaitu estimasi nilai ekonomi dalam satuan moneter(sering disebut valuasi ekonomi) dari dampak kesehatan akibat pencemaran merupakan sesuatu yang cukup kompleks karena kesehatan bukanlah suatu komoditas pasar yang sederhana.Konsep ini didasarkan pada teori ekonomi kesejahteraan (welfare economics) yang mengasumsikan bahwa kesehatan memiliki nilai selayaknya barang ekonomi lainnya, dan nilai tersebut dapat diperbandingkan. Secara lebih spesifik, teori tersebut mengasumsikan bahwa masyarakat cukup rasional dalam mengambil keputusan yang bersifat 'trade-off'antara risiko kesehatan (health risks) dan barang ekonomi lainnya (Septiyantie, 2013).

Dewasa ini telah berkembang berbagai teknik evaluasi untuk mengestimasi dampak ekonomi dari pencemaran terhadap kesehatan. Dampak kesehatan secara umum terdiri dari kesakitan (morbiditas) dan kematian (mortalitas). Metode umum yang digunakan untuk menilai biaya morbiditas adalah loss of earnings dan medical cost. Kombinasi kedua metode tersebut sering disebut dengan metode cost of illness (COI). Sementara itu, estimasi biaya mortalitas akibat pencemaran melibatkan teknik yang lebih kompleks dan seringkali menimbulkan kontroversi seputar masalah etika/moral terkait dengan pemberian satuan moneter pada nilai kehidupan (value of life). Oleh karena itu, para ahli tidak menggunakan biaya kematian dalam arti psikologis, tetapi melalui proksi berupa hilangnya penghasilan (forgone earning) akibat mati secara dini. Konsep ini dikenal dengan nilai hidup secara statistik atau Value of Statistical Life (VSL). Metode yang sering digunakan untuk mengestimasi biaya mortalitas adalah pendekatan modal manusia atau Human Capital (HC) dengan prinsip bahwa value of life seseorang ditentukan oleh tingkat produktivitas kerja yang biasanya diukur berdasarkan nilai sekarang (present value) dari aliran pendapatan di masa datang. Kelemahan dari pendekatan HC tersebut adalah tidak mampu mengestimasi preferensi seseorang tentang nilai hidupnya, sehingga dalam praktiknya pendekatan ini sudah jarang digunakan.Sebagai alternatif, VSL biasanya diestimasi melalui kesediaan membayar atau willingness to pay (WTP) masyarakat terhadap pengurangan, bukan penghindaran, tingkat risiko kematian (Yaduma, 2012).

Studi tentang dampak ekonomi dari pencemaran udara terhadap kesehatan telah banyak dilakukan dalam beberapa tahun terakhir, baik pada tingkat negara maupun tingkat daerah (biasanya kota) dalam satu negara. Indikator pencemaran udara yang digunakan berbeda-beda, tetapi sebagian besar menggunakan $\mathrm{PM}_{10}$. Penilaian dampak kesehatan akibat pencemaran pada studi tersebut dilakukan melalui metode DoseResponse Function (DRF). Sementara itu, biaya ekonomi dari dampak kesehatan tersebut diestimasi oleh pendekatan value of statistical life (VSL) untuk mortalitas dan costs of illness (COI) untuk morbiditas. Hasil studi menunjukkan besarnya biaya mortalitas yang diakibatkan oleh konsentrasi $\mathrm{PM}_{10}$ adalah US\$ 1.773 juta atau setara dengan 2.09\% dari PDB (Produk Domestik Bruto), sedangkan biaya morbiditas sekitar US\$1.889,33 juta atau setara dengan 2.22\% dari PDB Singapura tahun 1999.

Pada kasus di Indonesia, studi tentang dampak kesehatan dari pencemaran udara 
pada umumnya dilakukan pada tingkat kota, diantaranya di Kota Jakarta yang menggunakan TSP (Total Suspended Particulates) dan $\mathrm{PM}_{10}$ di Kota Yogyakarta yang menggunakan $\mathrm{PM}_{10}$ dan $\mathrm{Pb}$ (timbal) sebagai indikator pencemaran udara. Berbeda dengan kedua studi tersebut, penelitian ini dilakukan pada tingkat negara, yaitu lndonesia,yang difokuskan pada konsentrasi $\mathrm{PM}_{10}$.Tujuan umum dari penelitian adalah untuk mengestimasi dampak ekonomi dari pencemaran udara terhadap kesehatan. Secara spesifik, tujuan tersebut dapat dirinci sebagai berikut: (1) mengestimasi jumlah kasus mortalitas dan morbiditas akibat dari konsentrasi $\mathrm{PM}_{10}$; dan (2) melakukan valuasi biaya ekonomi dari mortalitas dan morbiditas tersebut.

\section{Metode}

Penelitian ini menggunakan pendekatan kuantitatif yang menekankan analisis pada data berupa angka atau fakta yang dikuantifikasi. Dampak ekonomi dari pencemaran udara terhadap kesehatan diukur oleh biaya ekonomi dari gangguan kesehatan akibat konsentrasi $\mathrm{PM}_{1}$. Besarnya biaya tersebut diestimasi melalui pendekatan matematis sebagai berikut.

$$
=d H_{i} \times V_{i}
$$

dimana: adalah besarnya biaya ekonomi untuk masing-masing kasus kesehatan i, adalah jumlah kasus kesehatan i; dan adalah besarnya biaya kesehatan per kasus untuk masing-masing kasus kesehatan i. Estimasi model matematika pada persamaan (1) tersebut memerlukan dua tahap dalam teknik analisis yang dijelaskan sebagai berikut.

Jumlah kasus kesehatan yang diakibatkan oleh konsentrasi $\mathrm{PM}_{10}$ diestimasi oleh pendekatan Dose Response Function (DRF) yang dinyatakan oleh rumus sebagai berikut.

$$
d H_{i}=b_{i} \times P O P_{i} \times d A(2)
$$

di mana: $d H_{i}$ adalah perubahan risiko masingmasing dampak kesehatan i, $b_{i}$ adalah koefisien dose-response function untuk masing-masing dampak kesehatan I; $P O P_{i}$ adalah jumlah penduduk yang terkena risiko kesehatan i; dan $d A$ adalah perubahan konsentrasi ambien polutan.
Pendekatan dose-response function menjelaskan bagaimana kemungkinan dan tingkat keparahan suatu dampak kesehatan (response) berkaitan dengan jumlah dan konsentrasi suatu pencemar (dose).Prinsip utama dalam pendekatan ini adalah perubahan tingkat kualitas ambien untuk masing-masing pencemar dapat berhubungan secara statistik dengan perubahan pada masing-masing dampak kesehatan. Hubungan tersebut dinyatakan dalam sebuah koefisien doseresponse yang diperoleh melalui analisis regresi dan analisis kohort.

Langkah pertama dalam pendekatan DRF adalah menentukan dampak kesehatan (mortalitas dan morbiditas) akibat pencemaran (dalam kasus ini adalah konsentrasi $\mathrm{PM}_{10}$ ). Langkah ini merupakan studi epidemiologiyang ditujukan untuk mengidentifikasi beberapa dampak kesehatan akibat $\mathrm{PM}_{10}$. Tingkat risiko masing-masing dampak kesehatan tercermin pada koefisien DRF(symbol " $b_{i}$ " pada rumus 1). Pada penelitian ini koefisien DRF diadoptasi dari studi WHO (2002), yang dilakukan di delapan kota di Italia (lihat Tabel 1) dengan pertimbangan bahwa tren konsentrasi $\mathrm{PM}_{10} \mathrm{di}$ delapan kota tersebut relatif sama dengan Indonesia. Mengingat terdapat variasi nilai koefisien DRF pada studi-studi terdahulu, maka pada penelitian ini disertakan tiga asumsi alternatif, yaitu bawah, sentral, dan atas, seperti yang direkomendasikan oleh Yaduma pada tahun 2012.

Langkah kedua adalah menentukan jumlah penduduk yang berisiko terkena masing-masing dampak kesehatan $\left(\mathrm{POP}_{\mathrm{i}}\right)$. Dampak pencemaran udara dapat terjangkit pada seluruh penduduk atau pada kelompok usia tertentu. Mengacu pada WHO (2002) penduduk yang berpotensi terkena dampak untuk indikator kematian dini, perawatan rumah sakit akibat penyakit kardiovaskuler, perawatan rumah sakit akibat penyakit pernapasan, dan gangguan saluran pernapasan adalah seluruh penduduk. Adapun penduduk yang berpotensi menderita bronkitis akut dan serangan asma adalah kelompok penduduk berusia dibawah 18 tahun, sedangkan penduduk yang berisiko terkena dampak berupa jumlah hari tidak bekerja adalah kelompok penduduk berusia usia produktif. 
Tabel 1. Tingkat Risiko dari Dampak Kesehatan akibat Perubahan Konsentrasi $10 \mu \mathrm{g} / \mathrm{m}^{3} \mathrm{PM}_{10}$

\begin{tabular}{lccc}
\hline \multirow{2}{*}{ Jenis Dampak Kesehatan } & \multicolumn{3}{c}{ Faktor Risiko Relatif } \\
\cline { 2 - 4 } & Bawah & Sentral & Atas \\
\hline Kematian dini & 0.000896 & 0.002567 & 0.00421 \\
Perawatan rumah sakit akibat penyakit kardiovaskuler & 0.000598 & 0.000896 & 0.001292 \\
Perawatan rumah sakit akibat penyakit pernapasan & 0.001292 & 0.001587 & 0.00198 \\
Bronkitis akut & 0.012663 & 0.026697 & 0.04068 \\
Serangan asma & 0.004593 & 0.004974 & 0.005354 \\
Jumlah hari tidak bekerja & 0.007603 & 0.008984 & 0.010346 \\
Gangguan saluran pernapasan & 0.00198 & 0.006766 & 0.010436 \\
\hline Sumber: WHO (2002)
\end{tabular}

Sumber: WHO (2002)

Selanjutnya langkah terakhir adalah menentukan perubahan tingkat konsentrasi $\mathrm{PM}_{10}(\mathrm{dA})$. Secara matematis, perubahan tingkat konsentrasi $\mathrm{PM}_{10}$ adalah sebagai berikut

$$
=p_{1}-p_{0}
$$

dimana adalah konsentrasi $\mathrm{PM}_{10}$ pada tahun penelitian dan adalah baseline concentration, yaitu konsentrasi terendah dimana dampak kesehatan mulai dapat dirasakan.

Pada umumnya baseline concentration diambil sebagai konsentrasi dasar untuk pencemaran udara, tetapi sebagian besar studi merekomendasikan bahwa tidak ada tingkat ambien minimum untuk $\mathrm{PM}_{10}$ di mana dampak negatif kesehatan mulai muncul. Ini berarti risiko kesehatan terjadi pada setiap tingkat paparan $\mathrm{PM}_{10}$. Mengacu pada pendapat tersebut, penelitian ini menggunakan zero ambient concentration level sebagai baseline concentrationdari $\mathrm{PM}_{10}$.

Teknik valuasi yang digunakan untuk mengestimasi biaya ekonomi dari pencemaran terhadap kesehatan adalah pendekatan Value of Statistical Life (VSL) berdasarkan Willingness To Pay (WTP) untuk kasus mortalitas dan pendekatan Costs of Illness (COI) untuk kasus morbiditas. Pendekatan VSL didasarkan pada preferensi individu yang tercermin dari kesediaan seseorang untuk membayar pengurangan tingkat risiko kematiannya. Sementara itu, pendekatan COI terdiri dari biaya berobat secara medis (medical costs) dan hilangnya produktivitas yang dicerminkan oleh hilangnya pendapatan seseorang akibat sakit (loss of productivity).

Untuk mengestimasi VSL dan COI diperlukan survei atau pengamatan perilaku dan preferensi individu secara menyeluruh, yang membawa konsekuensi pada kendala waktu dan biaya. Sebagaimana studi-studi terdahulu, penelitian ini menggunakan pendekatan Benefit Transfer (BT), yaitu metode sekunder (secondary methods) yang menggunakan hasil dari studi-studi primer terdahulu dengan penyesuaian nilai parameter untuk menangkap perbedaan karakteristik lokasi dan sosialekonomi penelitian. Pendekatan BT terdiri dari tiga jenis metode, yaitu penyesuaian preferensi (preference calibration), transfer nilai (value transfer), dan analisis meta-regresi (metaregression analysis) (Yaduma, 2012). Metode penyesuaian preferensi mengintegrasikan fungsi preferensi individu dengan informasi mengenai nilai manfaat (VSL) yang tersedia, sedangkan metode transfer nilai menyesuaikan estimasi nilai VSL suatu negara dengan negara yang bersangkutan. Adapun metode metaregression analysis merupakan metode statistik yang mengkombinasikan hasil studi VSL dari berbagai negara untuk menghasilkan suatu fungsi VSL yang kemudian digunakan sebagai nilai VSL negara yang bersangkutan.

Jenis metode dalam pendekatan BT yang digunakan dalam penelitian ini adalah transfer nilai (Value Transfer) dengan alasan utama adalah aspek kesederhanaan, sehingga mudah untuk dilakukan perhitungan. Penyesuaian nilai VSL dan COI menggunakan rasio paritas daya beli (purchasing power parity) antara dua negara.Pada penelitian ini, besarnya biaya ekonomi per kasus kesehatan mengacu pada studi EPA yang dilakukan di Amerika Serikat. Oleh karena itu, rasio paritas daya beli yang digunakan adalah negara Indonesia dengan Amerika Serikat. Secara matematis, besarnya nilai COI dan VSL dihitung sebagai berikut

$$
S L_{i}=\left[\frac{G N P_{I N D}}{G N P_{U S A}}\right]^{=} \times E R \times V S L_{U S A} \text { (4) }
$$




$$
I_{i}=\left[\frac{G N I_{I N D}}{G N I n S A}\right]^{e} \times E R \times C O I_{U S A}
$$

dimana: $V S L_{i}$ adalah value of statistical life untuk kasus mortalitas di Indonesia; $V S L_{U S A}$ adalah value of statistical life untuk kasus mortalitas di Amerika Serikat; $\mathrm{COI}_{i}$ adalah cost of illness untuk masing-masing kasus morbiditas di Indonesia; $\mathrm{COI}_{\text {USA }}$ adalah cost of illness untuk masing-masing kasus morbiditas

di Amerika Serikat; $\frac{G N I_{I N D}}{G N I U S A}$ adalah rasio paritas daya beli antara Indonesia dan Amerika Serikat yang dihitung dari perbandingan nilai Gross National Income per capita (GNI) masing-masing negara; $E R$ adalah nilai tukar rupiah terhadap dollar Amerika Serikat; dan $e$ adalah tingkat elastisitas dari Willingness To $\operatorname{Pay}$ (WTP).

Salah satu komponen penting dalam metode value transfer adalah tingkat elastisitas WTP (e), yang menunjukkan perubahan kesediaan membayar masyarakat untuk pengurangan tingkat risiko kematian marjinal akibat perubahan pendapatan. Pada studi-studi terdahulu, tingkat elastisitas (e) diasumsikan 1.0 untuk kasus di negara-negara berkembang. Namun dalam praktiknya, parameter tersebut tidak selalu bernilai konstan, tetapi dapat bervariasi bergantung pada tingkat pendapatan negara yang diteliti. Oleh karena itu, untuk mengurangi ketidakpastian dalam parameter elastisitas. Yaduma (2012), menyarankan penggunaan tiga skenario nilai elastisitas (tinggi, menengah, rendah) yang masingmasing bernilai 1.0; 1.5; dan 2.0 dalam analisis risiko kesehatan pada kasus di negara-negara berkembang.

Teknik estimasi melibatkan beberapa variabel penelitian dengan definisi operasional dan pengukuran yang dijelaskan pada Tabel 2 . Data yang digunakan dalam estimasi adalah data berskala makro pada tingkat negara (Indonesia) pada satu tahun tertentu (2011) yang merupakan data terakhir yang tersedia. Data tersebut merupakan data sekunder berupa laporan dan penelitian terdahulu yang dipublikasikan oleh berbagai institusi. Metode pengumpulan data dilakukan melalui studi kepustakaan.

\section{Hasil dan Pembahasan}

Berdasarkan pendekatan Dose

Response Function (DRF) pada persamaan (2), estimasi jumlah kasus kesehatan $(\mathrm{dH})$ akibat konsentrasi $\mathrm{PM}_{10}$ memerlukan informasi koefisien dose response (b), jumlah penduduk yang berpotensi terkena dampak (POP), dan perubahan tingkat konsentrasi $\mathrm{PM}_{10}(\mathrm{dA})$. Nilai koefisien dose response diadopsi dari studi WHO (2002) seperti yang terangkum pada Tabel 1. Jumlah penduduk yang berisiko terkena dampak kesehatan akibat konsentrasi $\mathrm{PM}_{10}$ berbeda untuk setiap jenis indikator kesehatan. Sementara itu, konsentasi $\mathrm{PM}_{10}$ pada tahun 2011 adalah sebesar 46,74 $\mu \mathrm{g} /$ $\mathrm{m}^{3}$ dimana angka tersebut melebihi ambang batas yang ditetapkan oleh WHO sebesar 20 $\mu \mathrm{g} / \mathrm{Nm}^{3}$. Namun demikian, mengacu pada studi-studi terdahulu yang menggunakan zero ambient concentration level sebagai baseline concentration dari $\mathrm{PM}_{10}$, maka besarnya perubahan tingkat konsentrasi $\mathrm{PM}_{10}$ (dA) dalam penelitian ini sebesar konsentrasi $\mathrm{PM}_{10}$ yang terjadi pada tahun 2011, yaitu $46,74 \mu \mathrm{g} /$ $\mathrm{m}^{3}$.

Indikator mortalitas yang digunakan dalam penelitian ini adalah kematian dini (premature deaths) yaitu kematian yang terjadi sebelum usia 70 tahun. Menurut WHO (2011), paparan konsentrasi $\mathrm{PM}_{10}$ meningkatkan risiko kematian dini baik dalam jangka pendek maupun jangka panjang, terutama yang disebabkan oleh penyakit kardiopulmonari dan kanker paru-paru. Jumlah penduduk berisiko terkena dampak sama dengan jumlah total penduduk Indonesia pada tahun 2011 yaitu 243.801.639 jiwa. Dengan tingkat kematian kasar (crude death rate - CDR) pada tahun 2011 adalah 6,289 per 1.000 penduduk, maka mengacu persamaan (2) diperoleh jumlah kasus kematian dini akibat $\mathrm{PM}_{10}$ sebanyak 183.956 kasus (estimasi sentral), dengan estimasi bawah dan estimasi atas masing-masing sebanyak 64.213 kasus dan 301.732 kasus (lihat Tabel 3). Jumlah kematian tersebut setara dengan $11,86 \%$ terhadap jumlah kasus kematian akibat Penyakit Tidak Menular (PTM).

Sementara itu, morbiditas merupakan angka kesakitan, baik insidensi maupun 
Tabel 2. Variabel-Variabel Penelitian

\begin{tabular}{|c|c|c|}
\hline Variabel & Definisi dan Pengukuran & Sumber \\
\hline Konsentrasi $\mathrm{PM}_{10}$ & $\begin{array}{l}\text { Partikel halus tersuspensi yang berdiameter kurang dari } 10 \\
\text { mikron yang diukur dari rata-rata eksposur tahunan luar } \\
\text { ruangan (outdoor pollution) di daerah perkotaan suatu negara } \\
\text { dalam satuan } \mu \mathrm{g} / \mathrm{m}^{3} \text { (microgram per meter kubik) }\end{array}$ & $\begin{array}{l}\text { World Development } \\
\text { Indicators (World Bank, } \\
\text { 2014) }\end{array}$ \\
\hline Jumlah penduduk & $\begin{array}{l}\text { Jumlah penduduk berisiko terkena dampak atau memiliki } \\
\text { potensi terjangkit penyakit tertentu akibat paparan konsentrasi } \\
\mathrm{PM}_{10} \text { yang dinyatakan dalam satuan jiwa. }\end{array}$ & $\begin{array}{l}\text { World Development } \\
\text { Indicators (World Bank, } \\
\text { 2014), dan Biro Pusat } \\
\text { Statistik (2013) }\end{array}$ \\
\hline Costs of illness (COI) & $\begin{array}{l}\text { Segala jenis biaya yang digunakan untuk perawatan kesehatan } \\
\text { (health care costs) yang dinyatakan dalam satuan US\$. }\end{array}$ & $\begin{array}{l}\text { Penelitian } \\
(1994) \\
\text { EPA(2011) }\end{array}$ \\
\hline $\begin{array}{l}\text { Value of statistical life } \\
\text { (VSL) }\end{array}$ & $\begin{array}{l}\text { Nilai hidup secara statistik yang diukur oleh kesediaan untuk } \\
\text { membayar atau willingness to pay (WTP) dalam rangka } \\
\text { pengurangan tingkat risiko dari kematian dalam satuan US\$. }\end{array}$ & $\begin{array}{l}\text { Penelitian Ostro (1994), } \\
\text { dan EPA (2011) }\end{array}$ \\
\hline Paritas daya beli & $\begin{array}{l}\text { Perbandingan tingkat daya beli antara dua negara yang diukur } \\
\text { berdasarkan tingkat pendapatan nasional bruto per kapita } \\
\text { (Gross National Income Product per capita) atas dasar harga } \\
\text { berlaku pada tahun } 2011 \text {. }\end{array}$ & $\begin{array}{l}\text { World Development } \\
\text { Indicators (World Bank, } \\
\text { 2014) }\end{array}$ \\
\hline
\end{tabular}

prevalensi dari suatu penyakit, yang menggambarkan kejadian penyakit dalam suatu populasi masyarakat pada kurun waktu tertentu. Dalam penelitian ini indikator morbiditas yang digunakan mengacu pada WHO (2002), yaitu perawatan rumah sakit akibat penyakit kardiovaskuler, perawatan rumah sakit akibat penyakit pernapasan, bronkitis akut, serangan asma, jumlah hari tidak bekerja, serta gangguan saluran pernapasan. Jumlah penduduk berisiko terkena dampak untuk masing-masing indikator morbiditas tersebut berbeda-beda seperti yang dijelaskan sebelumnya. Dengan jumlah penduduk Indonesia tahun 2011 sebanyak 243.801.639 jiwa, maka estimasi sentral jumlah perawatan rumah sakit akibat penyakit kardiovaskuler sebanyak 10.201.361 kasus, jumlah perawatan rumah sakit akibat penyakit pernapasan sebanyak 18.088.984 kasus, dan gangguan saluran pernapasan sebanyak 77.102.582 kasus. Selanjutnya dari jumlah penduduk tersebut, proporsi penduduk yang berusia di bawah 18 tahun sebesar 30\% atau sekitar 73.140.492 jiwa, sedangkan penduduk usia kerja (di atas 15 tahun) sebesar 65\% atau sekitar 158.471.065 jiwa. Berdasarkan informasi tersebut, maka estimasi sentral jumlah penderita bronkitis akut sebanyak 304.233.119 kasus, dan serangan asma sebanyak 56.685.196 kasus. Adapun estimasi sentral jumlah hari tidak bekerja sebanyak 102.380.855 kasus. Dengan menjumlahkan semua kasus tersebut diketahui bahwa jumlah kasus morbiditas total akibat konsentrasi $\mathrm{PM}_{10}$ di Indonesia adalah 568.701.096 kasus (estimasi sentral) (lihat Tabel 3). Dari angka tersebut, lebih dari separuh (sekitar 53\%) berupa kasus bronkitis akut.

Besarnya biaya ekonomi dari gangguan kesehatan yang diakibatkan dari konsentrasi $\mathrm{PM}_{10}$ diestimasi menggunakan persamaan (1). Secara matematis, biaya tersebut merupakan hasil perkalian antara jumlah kasus kesehatan yang dihitung dari persamaan (2) dengan biaya ekonomi dari masing-masing kasus kesehatan seperti pada persamaan (4) untuk mortalitas dan persamaan (5) untuk morbiditas. Beberapa informasi penting pada tahun 2011 yang diperlukan untuk perhitungan biaya ekonomi tersebut adalah sebagai berikut (World Bank, 2014): (1) nilai GNI Indonesia adalah US\$ 3.368,319 dan Amerika Serikat adalah US\$ $50.863,886$, sehingga rasio paritas daya beli adalah 0,0662; (2) nilai tukar (kurs) rupiah terhadap dollar Amerika Serikat adalah Rp 8.770,43 per US\$; dan (3) laju inflasi di Amerika Serikat sebesar $11,6 \%$.

Berdasarkan studi EPA (2011), nilai VSL untuk kasus mortalitas berupa kematian dini di Amerika Serikat pada tahun 2010 adalah US\$ 7.400.000 per kasus. Dengan melibatkan informasi tentang rasio paritas daya beli, nilai tukar, dan laju inflasi seperti yang telah diuraikan, maka diperoleh biaya mortalitas per kasus senilai Rp 1.234 juta atau sekitar Rp 1,2 $(\mathrm{e}=1,5)$. Selanjutnya berdasarkan persamaan (1) 
Tabel 3. Jumlah Kasus Kesehatan Akibat Konsentrasi PM $_{10}$

\begin{tabular}{llll}
\hline \multirow{2}{*}{ Jenis Dampak Kesehatan } & \multicolumn{3}{c}{ Jumlah Kasus } \\
\cline { 2 - 4 } Mortalitas: kematian dini & \multicolumn{1}{c}{ Bawah } & \multicolumn{1}{c}{ Sentral } \\
Morbiditas & 64.213 & 183.956 & 301.732 \\
Perawatan RS akibat penyakit kardiovaskuler & 327.398 .728 & 568.701 .096 & 798.705 .600 \\
Perawatan RS akibat penyakit pernapasan & 6.817 .062 & 10.210 .361 & 14.719 .099 \\
Bronkitis akut & 14.719 .099 & 18.088 .984 & 22.566 .719 \\
Serangan asma & 144.308 .298 & 304.233 .119 & 463.579 .195 \\
Jumlah hari tidak bekerja & 52.339 .787 & 56.685 .196 & 61.014 .098 \\
Gangguan saluran pernapasan & 86.647 .765 & 102.380 .855 & 117.899 .688 \\
\hline Sumber: WHO (2002) & 22.566 .719 & 77.102 .582 & 118.926 .801 \\
\hline
\end{tabular}

Sumber: WHO (2002)

diperoleh besarnya biaya ekonomi untuk kasus mortalitas (kematian dini) akibat konsentrasi $\mathrm{PM}_{10}$ di Indonesia pada tahun 2011 adalah Rp 227.142.955 juta atau sekitar Rp 227,1 triliun $(\mathrm{e}=1,5)$ (lihat Tabel 4). Biaya mortalitas (kematian dini) tersebut menunjukkan manfaat yang hilang karena masyarakat meninggal lebih 'dini' dibandingkan dengan tingkat rata-rata harapan hidup mereka.

Studi EPA juga melaporkan biaya ekonomi per kasus morbiditas di Amerika Serikat pada tahun 2010 dengan metode COI sebagai berikut: (1) perawatan rumah sakit akibat penyakit kardiovaskuler adalah US\$ 29.364; (2) perawatan rumah sakit akibat penyakit pernapasan adalah US\$ 23.711; (3) bronkitis akut adalah USS 416; (4) serangan asma adalah US\$ 50; (5) jumlah hari tidak bekerja adalah US\$ 149: serta (6) gangguan saluran pernapasan adalah US\$ 18 . Menggunakan informasi yang sama seperti pada kasus mortalitas seperti rasio paritas daya beli, nilai tukar, dan laju inflasi, maka berdasarkan persamaan (1) diperoleh biaya ekonomi akibat morbiditas total di Indonesia senilai $\mathrm{Rp}$ 145.963.037 juta atau sekitar $\mathrm{Rp}$ 146 triliun $(e=1,5)$. Komponen terbesar dari biaya tersebut adalah perawatan rumah sakit akibat penyakit pernapasan, yaitu sekitar $\mathrm{Rp}$ 71,6 triliun atau mencapai hampir 50\% dari biaya morbiditas total. Adapun besarnya biaya ekonomi untuk kasus morbiditas lainnya dapat dilihat pada Tabel 4 .

Hasil estimasi biaya ekonomi total akibat konsentrasi $\mathrm{PM}_{10}$ di Indonesia tahun 2011 sekitar Rp 373, 1 triliun, dengan komposisi sekitar $60,9 \%$ adalah biaya mortalitas (kematian dini) dan $39,1 \%$ berupa biaya morbiditas.
Dengan nilai PDB Indonesia pada tahun yang sama sekitar 7.419,2 triliun (World Bank, 2014), maka konsentrasi $\mathrm{PM}_{10}$ memberikan beban sebesar 5,03\% terhadap kinerja pembangunan ekonomi (diukur dengan PDB). Dari biaya total tersebut, biaya mortalitas memberikan beban yang relatif lebih tinggi dibandingkan biaya mortalitas, yaitu sekitar 3,06\% berbanding 1,97\% (lihat Tabel 5). Hasil estimasi dalam penelitian ini relatif sama yang menyimpulkan bahwa biaya ekonomi dari konsentrasi PM10 di China mencapai $4,31 \%$ dari PDB yang terdiri dari biaya mortalitas sebesar 2,09\% dan biaya morbiditas sebesar 2,20\%.

Pada akhirnya biaya ekonomi akibat konsentrasi $\mathrm{PM}_{10}$ terhadap kesehatan tersebut harus ditanggung oleh masyarakat sebagai dampak negatif (eksternalitas) dari pembangunan ekonomi atau sering disebut sebagai biaya pembangunan. Dengan jumlah penduduk Indonesia tahun 2011 sebesar 243.801.639 jiwa, maka biaya yang harus ditanggung per orang (per kapita) sebesar Rp $1.530 .367,04$ atau sekitar US\$ 174,5 , yang terdiri dari biaya mortalitas sebesar Rp 931.671,16 atau sekitar US\$ 106,2 dan biaya morbiditas sebesar Rp 598.695,88 atau sekitar US\$ 68,3. Dengan pendapatan per kapita Indonesia pada tahun yang sama senilai $\mathrm{Rp} 10.184 .548,83$, maka setiap orang Indonesia harus menanggung biaya tersebut sekitar rata-rata $6,7 \%$ dari pendapatannya. Jika dibandingkan dengan beberapa studi terdahulu, maka biaya per kapita tersebut lebih rendah dibandingkan dengan di China senilai US\$ 265 dan di Inggris (Pearce, 1995) yang mencapai US\$ 848. Fakta ini menunjukkan bahwa biaya pencemaran yang harus ditanggung oleh masyarakat berkorelasi 
Tabel 4. Biaya Ekonomi Akibat Konsentrasi PM10 (dalam juta Rupiah)

\begin{tabular}{llll}
\hline \multirow{2}{*}{ Jenis Dampak Kesehatan } & \multicolumn{3}{c}{ Biaya Ekonomi } \\
\cline { 2 - 4 } & \multicolumn{1}{c}{$\mathbf{e = 1}$} & $\mathbf{e}=\mathbf{1 , 5}$ & $\mathbf{e = 2}$ \\
\hline Mortalitas: kematian dini & 882.688 .122 & 227.142 .956 & 58.452 .232$. \\
Morbiditas & 567.206 .321 & 145.963 .037 & 37.561 .655 \\
Perawatan RS akibat penyakit kardiovaskuler & 194.404 .839 & 50.027 .511 & 12.873 .917 \\
Perawatan RS akibat penyakit pernapasan & 278.108 .858 & 71.567 .632 & 18.416 .982 \\
Bronkitis akut & 82.063 & 21.117 .982 & 5.434 .433 \\
Serangan asma & 1.837 .766 & 472.924 & 121.700 \\
Jumlah hari tidak bekerja & 9.891 .355 & 2.545 .409 & 655.027 \\
Gangguan Saluran Pernapasan & 899.895 & 231.576 & 59.593 \\
\hline Total & 1.449 .874 .443 & 373.105 .993 & 96.013 .887 \\
\hline
\end{tabular}

Sumber: WHO (2002)

Tabel 5. Rekapitulasi Biaya Ekonomi Akibat Konsentrasi PM10

\begin{tabular}{|c|c|c|c|c|}
\hline \multirow[b]{2}{*}{ Kasus Kesehatan } & \multicolumn{2}{|c|}{ Biaya Ekonomi $(e=1,5)$} & \multirow{2}{*}{$\begin{array}{c}\text { Share } \\
\text { terhadap } \\
\text { PDB }\end{array}$} & \multirow{2}{*}{$\begin{array}{l}\text { Biaya Ekonomi } \\
\text { per kapita }(\mathrm{Rp})\end{array}$} \\
\hline & Nilai & $\begin{array}{c}\text { Proporsi } \\
(\%)\end{array}$ & & \\
\hline Mortalitas. kematian dini & 227.142 .955 .633 .550 & 60.9 & 3.062 & 931.671 .16 \\
\hline $\begin{array}{l}\text { Mortalltas: kematian dını } \\
\text { Morbiditas }\end{array}$ & 145.963 .037 .551 .632 & 39.1 & 1.967 & 598.695 .88 \\
\hline Perawatan RS akibat penyakit kardiovaskuler & 50.027 .511 .625 .127 & 13.4 & 0.674 & 205.197 .60 \\
\hline Perawatan RS akibat penyakit pernapasan & 71.567 .632 .756 .291 & 19.2 & 0.965 & 293.548 .61 \\
\hline Bronkitis akut & 21.117.982.616.481 & 5.7 & 0.285 & 86.619 .53 \\
\hline Serangan asma & 472.924 .988 .904 & 0.1 & 0.006 & 1.939 .79 \\
\hline Jumlah hari tidak bekerja & 2.545.409.304.774 & 0.7 & 0.034 & 10.440 .49 \\
\hline Gangguan Saluran Pernapasan & 231.576 .260 .056 & 0.1 & 0.003 & 949.86 \\
\hline Total & 373.105 .993 .185 .182 & 100.0 & 5.029 & 1.530 .367 .04 \\
\hline
\end{tabular}

Sumber: WHO (2002)

positif dengan kemajuan ekonomi suatu negara.

\section{Penutup}

Berdasarkan hasil dan pembahasan, maka dapat ditarik kesimpulan bahwa pencemaran udara (diukur konsentrasi $\mathrm{PM}_{10}$ ) di Indonesia mengakibatkan biaya ekonomi sekitar $\mathrm{Rp} 373.1$ triliun atau setara dengan 5.03\% Produk Domestik Bruto (PDB) tahun 2011. Biaya ekonomi tersebut terdiri dari biaya mortalitas berupa kematian dini senilai Rp 227,1 triliun $(60,9 \%$ biaya total) dan biaya morbiditas senilai 146 triliun $(39,1 \%$ dari biaya total $)$ dimana komponen terbesar (sekitar 50\%) dari biaya morbiditas tersebut adalah perawatan rumah sakit akibat penyakit pernapasan. Biaya ekonomi dari pencemaran merupakan beban yang harus ditanggung oleh masyarakat dengan rata-rata sekitar Rp 1,53 juta atau sekitar 6,7\% dari pendapatan per kapita per tahun.

Berdasarkan hasil tersebut, maka diperlukan kebijakan untuk mengurangi tingkat pencemaran udara di Indonesia, khususnya $\mathrm{PM}_{10}$.Kebijakan tersebut diarahkan pada pengendalian sumber utama dari pencemaran udara tersebut, yaitu sektor transportasi dan sektor industri. Di bidang transportasi beberapa alternatif kebijakan yang dapat dilakukan adalah pembatasan jumlah kendaraan bermotor, pengadaan dan perbaikan manajemen transportasi publik, dan menciptakan sustainable transportation yang meliputi aspek efficiency, equity, dan environmentally. Sementara itu, kebijakan di bidang industri diantaranya meningkatkan efisiensi energi dan penggunaan energi alternatif yang ramah lingkungan, menerapkan pajak emisi, dan mewujudkan green industry.

Penelitian ini mengandung beberapa keterbatasan yang dapat dijadikan sebagai masukan untuk studi-studi selanjutnya. Pertama, selain $\mathrm{PM}_{10}$, terdapat beberapa indikator pencemaran udara lain yang mempunyai keterkaitan erat dengan kesehatan (health-risk of air pollutants), diantaranya ozone $\left(\mathrm{O}_{3}\right)$, Carbon Monoksida, (CO), Nitrogen Dioksida $\left(\mathrm{NO}_{2}\right)$, Sulfur Dioksida $\left(\mathrm{SO}_{2}\right)$, dan Timbal (Pb) (Nurjanah, 2014). Kedua, dampak dari pencemaran udara tidak hanya terhadap kesehatan, tetapi juga banyak aspek, diantaranya kesejahteraan (welfare), sumberdaya lingkungan (environmental resources). Dengan demikian, 
studi yang ditujukan untuk menutupi kedua keterbatasan tersebut akan memberikan hasil yang lebih komprehensif tentang dampak dari pencemaran udara.

Ucapan terima kasih ditujukan kepada semua pihak yang telah membantu proses penelitian ini. Secara khusus, kami mengucapkan terima kasih kepada: (1) Fakultas Ekonomi dan Bisnis, Universitas Airlangga, Surabaya atas pendanaan penelitian ini; dan (2) Nurul Fitri R. yang telah membantu proses pengumpulan dan pengolahan data.

\section{Daftar Pustaka}

Basri, S. dkk. 2015. Analisis Risiko KEsehatan Lingkungan (Mdel Pengukuran Risiko Pencemaran Udara terhadap Kesehatan). Jurnal Kesehatan 7 (2).

Mulyadi. 2015. Paparan Timbal Udara terhdap Timbal Darah, Hemoglabin, Cystatin C Serum Pekerja Pengecatan Mobil. Jurnal Kemas. 11 (1).

Nurjanah, KL. Mufid, A. 2014. Gangguan Fungsi
PAru dan Kadar Continine pada Urin Karyawan yang Terpapar Asap Rokok Orang Lain. Jurnal Kemas 10 (1).

Sengkey,SL., Jansen, F., Wallah, S., 2011. Tingkat Pencemaran Udara CO Akibat Lalu Lintas dengan Model Prediksi Polusi Udara Skala Mikro. Jurnal Kemas 1 (2): 119-126.

Septiyantie, UP., \& Cahyadin. 2013. Hubungan Antara Realisasi Dana Bantuan Operasional Kesehatan dengan Indikator Gizi KIA di Provinsi Jawa Tengah pada Tahun 2012. Jurnal Kebijakan Kesehatan Indonesia 2 (4).

Sugiarti. 2009. Gas Pencemar Udara dan Pengaruhnya Bagi Kesehatan Manusia. Jurnal Chemica 10 (1): 50-58.

WHO. 2000. Air Quality Guidelines for Europe. Copenhagen: WHO Regional Office for Europe.

Yaduma, N. 2012. Estimating Mortality and Economic Costs of Particulate Air Pollution in Developing Countries: The Case of Nigeria. Economics Discussion Paper Series. EDP Vol. 1223. 